HCP/T5433-01

$$
\text { DR. } 2811
$$

\title{
MASTER
}

\section{Criteria for an Ideal Solar Photovoltaic Powered Industry}

February 1979

Published June 1979

Prepared for:

U.S. Department of Energy

Assistant Secretary for Energy Technology

Division of Distributed Solar Technology

Under Contract No. ET-78-X-01-5433 


\section{DISCLAIMER}

This report was prepared as an account of work sponsored by an agency of the United States Government. Neither the United States Government nor any agency Thereof, nor any of their employees, makes any warranty, express or implied, or assumes any legal liability or responsibility for the accuracy, completeness, or usefulness of any information, apparatus, product, or process disclosed, or represents that its use would not infringe privately owned rights. Reference herein to any specific commercial product, process, or service by trade name, trademark, manufacturer, or otherwise does not necessarily constitute or imply its endorsement, recommendation, or favoring by the United States Government or any agency thereof. The views and opinions of authors expressed herein do not necessarily state or reflect those of the United States Government or any agency thereof. 


\section{DISCLAIMER}

Portions of this document may be illegible in electronic image products. Images are produced from the best available original document. 
Available from:

National Technical Information Service (NTIS)

U.S. Department of Commerce

5285 Port Royal Road

Springfield, Virginia 22161

Price: Printed Copy: $\$ 6.00$

Microfiche: $\$ 3.00$ 
HCP/T5433-01

Dist. Category UC-63

\section{Criteria for an Ideal Solar Photovoltaic Powered Industry}

February 1979

Published June 1979

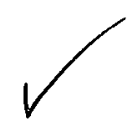

Prepared by:

Wizard Research and Development Group, Inc.

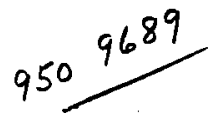

Washington, D.C. 20017

Prepared for:

U.S. Department of Energy

Assistant Secretary for Energy Technology Division of Distributed Solar Technology

Washington, D.C. 20585

Under Contract No. ET-78-X-01-5433

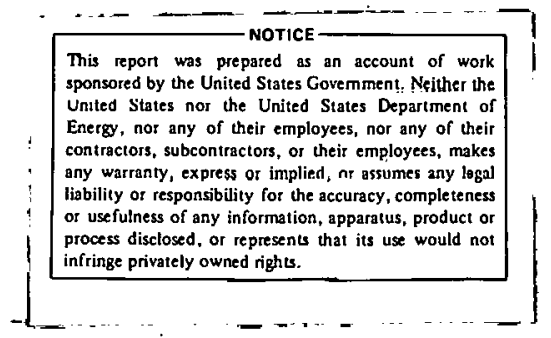




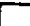

\section{NOTICE}

This report was preparad as an account of work sponsored by the United States Government. Neither the United States nor the United States Department of Energy. nor any of their employees, makes any warranty, express or implied, or assumes any logal liabilizy or responsibility for the eccuracy, completeness, or usefulness of any information, apparatus, product, or process disclosed, or represents that its use would not infringe privately owned rights. Reference herein to any specific commercial product, process, or service by trode name, mark, manufacturer, or otherwise, does not necessarily constitute or imply its endorsement, recommendation, or favoring by the United States Government or any agency thereof. The views and opinions of authors expressed herein do not necessorily state or reflect those of the United States Government or any apency thereof. 


\section{PREFACE}

This report was prepared under contract Number ET-78-X-01-5433 by Dr. David Barnett, Mr. Charles Jackson and Mr. Maurice Williams of Wizard Research and Development Group, Inc.

This report outlines a criteria for an ideal solar photovoltaic powered industry and assesses the industries in the Primary Metals industrial group with respect to this criteria.

This report was prepared for the Division of Solar Technology, U.S. Department of Energy. We are indebted to Mr. Paul Maycock, Department of Energy, for providing useful comments and guidance in the preparation of this report. 
THIS PAGE

WAS INTENTIONALLY

LEFT BLANK 


\section{EXECUT IVE SUMMARY}

This report is the result of a literature survey on tine applications of solar photovoltaic energy and the use of energy in the Primary Metals Industries. In this report we outline a criteria for an ideal solar photovoltaic powered industry and evaluate the. Primary Metals Industries with respect to this criteria.

Some of the major findings of this report are:

o The most important requirements of an ideal solar photovoltaic powered industry are the ability to use DC electrical power, ability to be located in Southern California or the Southwestern. U.S. and ability to do without power for -extended periods of time.

0 The costs of varying from the ideal are most severe with respect to the loss of, power element of the criteria.

- Although most of the industries in the Primary Metals group use tremendous amounts of electrical energy, the general requirements of an uninterruptable power source makes them less than ideal users of photovoltaic energy.

- It appears to be both technologically and economically feasible to develop processes which would make at least four of the seven members of the Primary Metals Industries ideal solar photovoltaic powered. industries. 


\section{TABLE OF CONTENTS}

PAGE

PREFACE

i

EXECUTIVE SUMMARY

i $i \mathrm{i}$

INTRODUCTION

1

CRITERIA FOR IDEAL SOLAR PHOTOVOLTAIC POWERED INDUSTRY

4

PRIMARY METALS AND THE IDEAL CRITERIA

54

CONCLUSION

60

BIBL IOGRAPHY

63 


\section{INTRODUCTION}

Direct conversion of sunlight to electrical energy has been technologically feasible for many years. However, as of yet, the economics of the various conversion processes have not al lowed them to be cost competitive with processes which convert fossil fuel energy to electrical energy. The two major problems with the sun as a source of electrical energy both stem from its lack of availability for constant use. One problem is caused by the day/night cycle of the sun. Depending on the latitude and the season of the year, sunlight is normally only available for less than half of a 24 hour diy. The other problem is that even during the time of day when the sun is in a position to deliver energy it may be obscured by cloud cover and thus rentered useless as a source of direct energy. In spite of these drawbacks to usinz the sun as a source of electrical energy, there are currently three categorias of solar photovoltaic power systems being considered and, in some cases, implemented for terrestrial use.

One category is the small modular solar cell array capable of producing 1 to $10 \mathrm{KW}$ electrical power. This type of array can be (and is being) used to provide power for relatively small isolated loads such as irrigation pumps, construction site power tools, communication equipment, battery recharging, remote area equipment, etc. This type of solar power supply is categorized by its portability and ability to deliver power in relatively isolated areas without the need of human intervention for long periods of time. Also in most of these applications the load can afford to do withnut power when direct sunlight is not available (i.e., at night or on cloudy days).

The second category of solar photovoltaic power source is the cooperative terrestrial power station producing 10 to $1000 \mathrm{kw}$ of electrical energy. This type of power supply is designed to be used by communities, business interests, 
or groups of individuals to supplement the conventional power supply and/or to provide peak power reserve. Also this category of solar photovoltaic power source could be used to supply power to small cities or businesses in remote or in fuel starved areas.

The third category is the full scale megawatt or larger power station which would be designed lu be a primary source of utility electricity. It is envisioned that these power stations would be built in desert areas having high probabilities for sunny days.

The thing which the above three categories have in common is all three are methods of adapting solar photovoltaic energy sources to existing applications. In essence, they are attempts at making solar photovoltaic energy emulate fossil fuel sources of electricity. These fossil fuel sources of electricity were designed to optimize the benefits of fossil fuels and minimize the negative effects of these fuels. A major characteristic of fossil fuel driven elertrical sources is 24 hour availability (it is uneconomical to turn modern electro-turbo generators oft ard on). As is common in engineering disciplines the processes which uses these energy sources are designed to fit the characteristics of the sources. As a result, it is not surprising. that most of the world's industries are designed to operate on a 24 hour basis. Non-availability on a 24 hour basis is one of the problems of trying to use solar photovoltaic energy as a subslitute for sy'slems which produce electrical energy using fossil fuels. Given that most applications requiring electrical cnergy were designed to take advantage of the 24 hour availability of this energy, it is not surprising that solar photovoltaic energy systems do not fare well when compared to fossil fuel electric systems. That overhead required to make solar photovoltaic energy available on a 24 hour basis makes 
the cost of this energy prohibitive when compared to fossil fuel derived electricity. Even in the future when the cost of solar photovoltaic arrays is in the 10 to 50 cent per peak Watt range the cost of this overhead will still add significantly to the delivered price of solar photovoltaic energy.

Although electricity derived from the sun will probably never be able to satisfy all of the earth's energy needs, it is still possible for it to make a significant contribution. This contribution could be greatly increased if more attention were paid to applications which are:

1) Presently able to use solar photovoltaic energy in the manner which it is delivered (i.e., sun follower applications);

2) Applications which are designed to take advantage of the good points of solar photovoltaic energy and minimize the negative effects of the bad points of this energy source.

It is the purpose of this study to define the type of industry which is best able to use solar photovoltaic energy as it is delivered. In so doinq we will attempt to characterize the solar photovoltaic power source and to characterize the ideal solar photovoltaic load. After we have developed a suitable charactcrization (ur criteria) for the ideal solar photovoltaic load, we will then examine the energy requirements of the primary metals industry to. see if there are any parts of this industry which fit the criteria of an idcal solar photovoltaic industry. 
CRITERIA FOR IDEAL SOLAR PHOTOVOLTAIC POWERED. INDUSTRY

$-8$ 
1) The ideal solar photovoltaic industry should be able to operate on $D C$ power.

In order to understand the need for this element of the criteria one must first understand a little about how photovoltaic cells work. Photovoltaic cells are semiconductor devices which can convert the energy in photons of light into $D C$ electrical energy. Most commercially available photovoltaic cells are made from single-crystal, high-purity silicon and minute amounts of trace elements such as boron and phosphorus. These elements are combined in such a way as to create a material with excess electrons (n-type semiconductor) connected to a material with insufficient electrons ( $p$-type region). The area where the materials are joined together can be likened to an exhausted battery. The shining of light on this area acts as a battery regenerator and as long as the area is illuminated by light electrical energy can be taken from the cell (see figure 1 ).

When a photovoltaic cell is exposed to light, the energy contained in the light photons is transferred to the electrons in the cell material. Some of this energy turns into heat and some of it moves electrons from relatively fixed positions in the material (i.e., lower energy levels) to a higher energy position in the material (called the conduction band) where they may move ahout more or less freely. Under the proper conditions these electrons contribute to the flow of electrical energy from the photovoltatc cell lu an electrical load such as a motor. The electrical energy generated by these cells is in the form of a DC voltage of approximately 0.5 volts (for a silicon cell with the incident light energy perpendicular to the cells surface) and a current which varies with the area of the photovoltaic ceil and with the wavelength and the intensity of the incident light. Currently available 


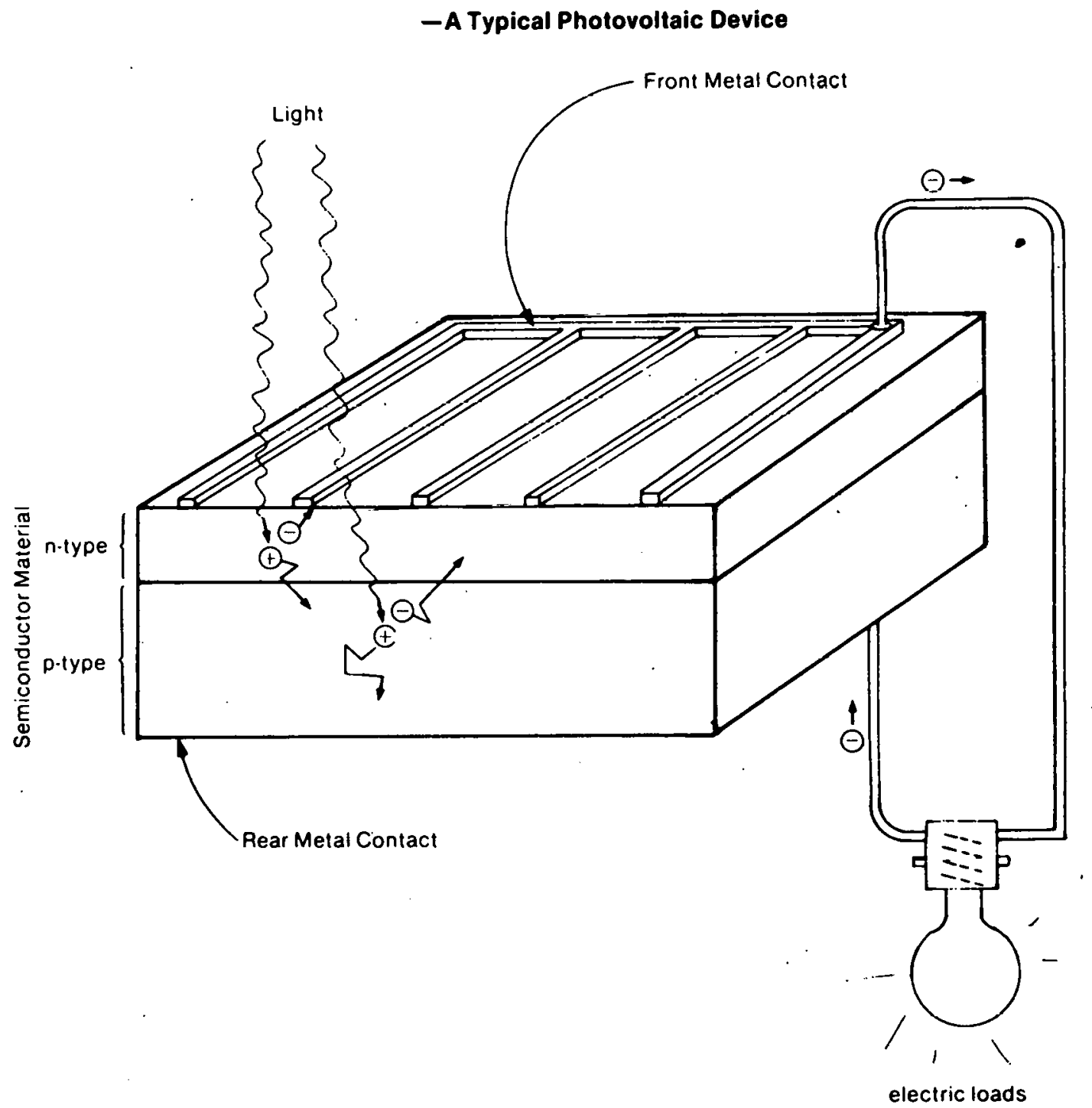

FIGURE 1 
silicon photovoltaic cells can deliver $0.12 \mathrm{~kW}$ to $0.16 \mathrm{~kW}$ of DC electricity per square meter of cell area.

Since photovoltaic cells deliver energy in the form of $D C$ electrical power, an industry which could use $O C$ power would have an advantage over an industry which required $A C$ power. How much of an advantage would depend on the amount and quality of the $A C$ power required. The device which is normally used to convert DC power to AC; power is called an inverter. Most modern inverters use solid state components based on silicon controlled rectifiers. These solid state devices are reliable and usually require little or no maintenance. Niost inverters in use today (mainly for battery powered systems) are line commutated (i.e., they rely on the utility system to establish the phase of frequericy of their A.C. output). Devices operating independently of the utility grid (self-commutated systems) are also available, but generally they are more expensive than line commutated devices.

The size of inverters varies from the small inverters used in on-site generating plants (e.g., wirlmill driven power plants) to larger devices which are part of the back-up power supplies like those used in hospitals and computer centers. The efficiency of modern solid state inverters is in the 92-95 percent $r$ ange when the devices are operating at more than about 25 percent of peak rapacity. Below this point, the efficiency falls off quite sharply since even at zero loads a lixed amounl or energy is consumed by the device itself. The cost of inverters varies depending upon the efficiency, reliability, quality of the output and the simplicity of the unit. Photovoltaic systems which use the utility grid for back-up power will be required to provide a well filtered output which matches the grid in frequency and phase and therefore will require a fairly expensive inverter. Estimates of inverters costs 
for solar photovoltaic power systems, vary from $\$ 51 / \mathrm{kw}$ for a large central power station to $\$ 200 / \mathrm{kw}$ for a small residential system. Assuming a cost for photovoltaic cells of 50 cents per peak watt (DOE 1986 goal) using an inverter to drive an $A C$ load with photovoltaic eneray could increase costs 10 to 40 percent of the cost of photovoltaic systems without inverters. 
2) The ideal solar photovoltaic powered industry should be located in areas which receive the maximum amount of sunshine possible.

The maximum amount of solar power which is received at the earth's surface is $1.0 \mathrm{kw} / \mathrm{m}^{2}$ of surface area. The actual amount of energy received at a given point varies with the cycle of night and day, the amount of cloud cover, the amount of atmospheric turbidity, the change of seasons and the amount of air pollution. An example of typical variations as a function of day-night cycles and seasonal change is given in figure 2 .

In the United States, the average amount of solar energy received varies from $9.4 \mathrm{kwh} / \mathrm{m}^{2}$ per day at Inyokern, in Southern California to $3.4 \mathrm{kwh} / \mathrm{m}^{2} \mathrm{per}$ day at Barrow, Alaska. Assuming an average insolation of $1.0 \mathrm{kw} / \mathrm{m}^{2}$, then Inyokern averages about 9.4 hours of sunshine per day and Barrow averages unly 3.4 hours per day.

Figure 3 and 4 illustrate the total amount of solar energy in $\mathrm{kwh} / \mathrm{m}^{2}$ falling on a horizontal surface in various parts of the U.S. during the months of June and December. Figures 5 and 6 show the amount of solar energy which would be received by sun tracking systems* for the same months.

These charts illustrate that contrary to what one might expect there is more variation in received solar energy as one goes from east to west than as one goes from north to south. Also as a general rule, western states receive more solar energy on an average than do eastern states. Consequently, large areas of Southern California and the southwestern United States appear to be more suitable (on the basis of this element of the criteria) for solar powered industries than other areas in the United States.

* I.e., a receiver system which kept the incoming solar radiation perpendicular to the surface of the receiver. 
Solar Energy Technology

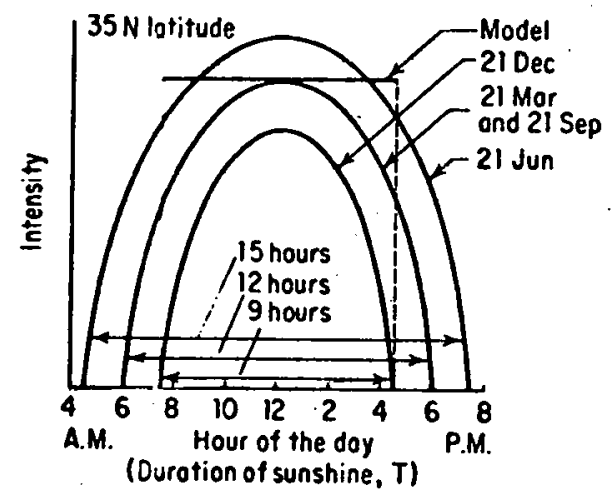




\section{FIGURE 3}

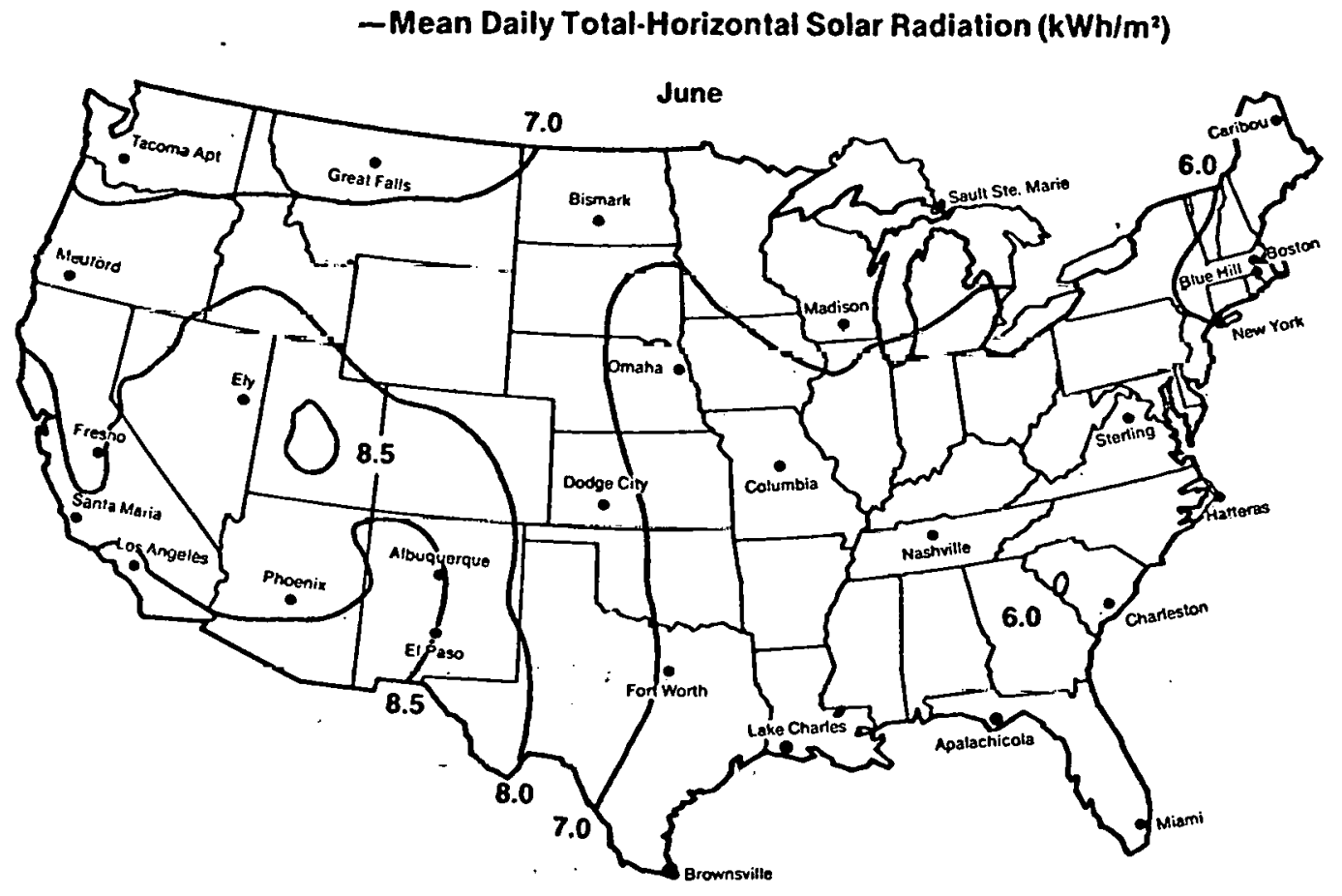


FIGURE 4

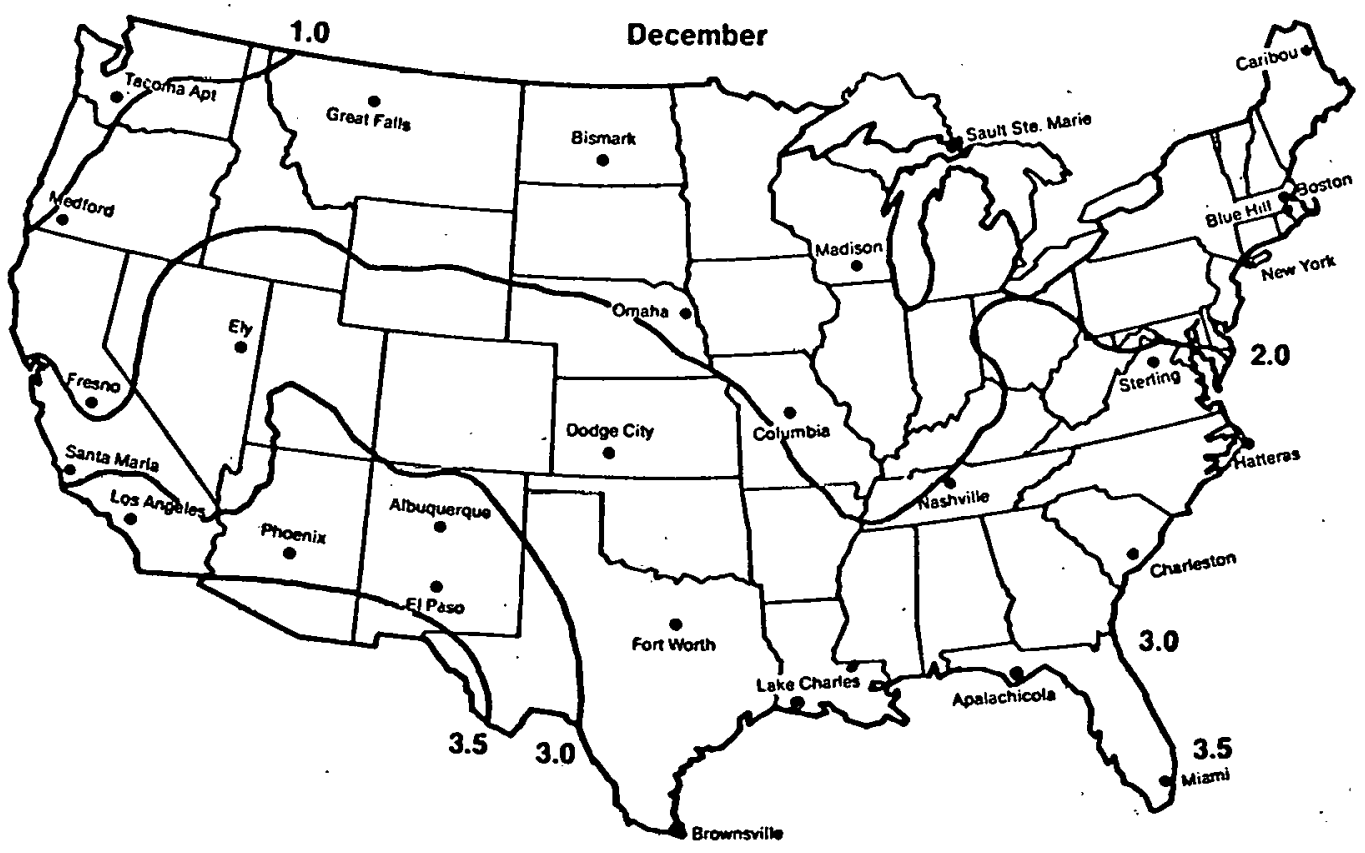

SOURCE: Boes, Eldon, et at., "Distribution of Direct and Total Solar Radiation Availabilities for the U.S.A." published by Sandia" Laboratories (SAND76-0411) 


\section{FIGURE 5}

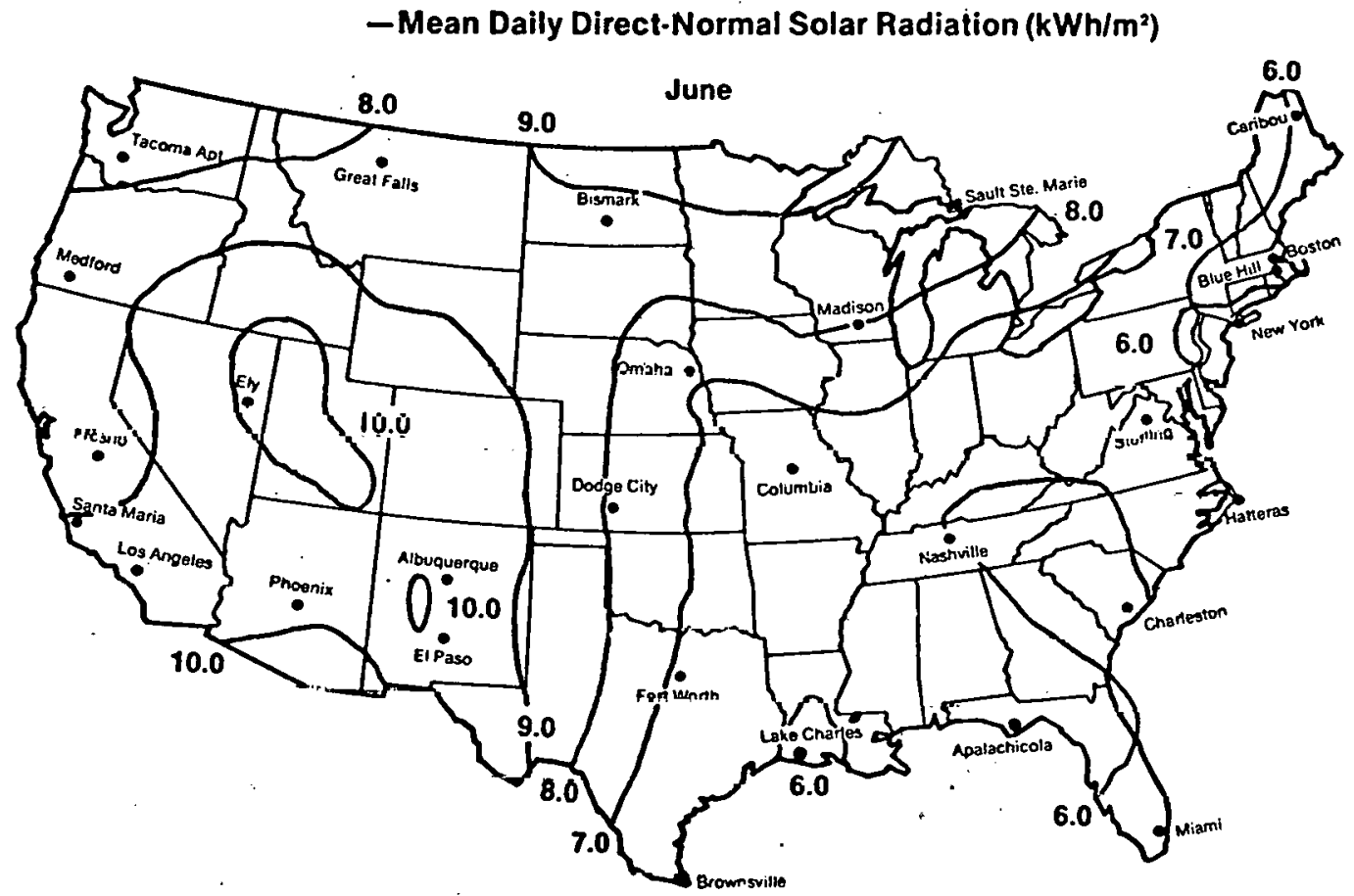


FIGURE 6

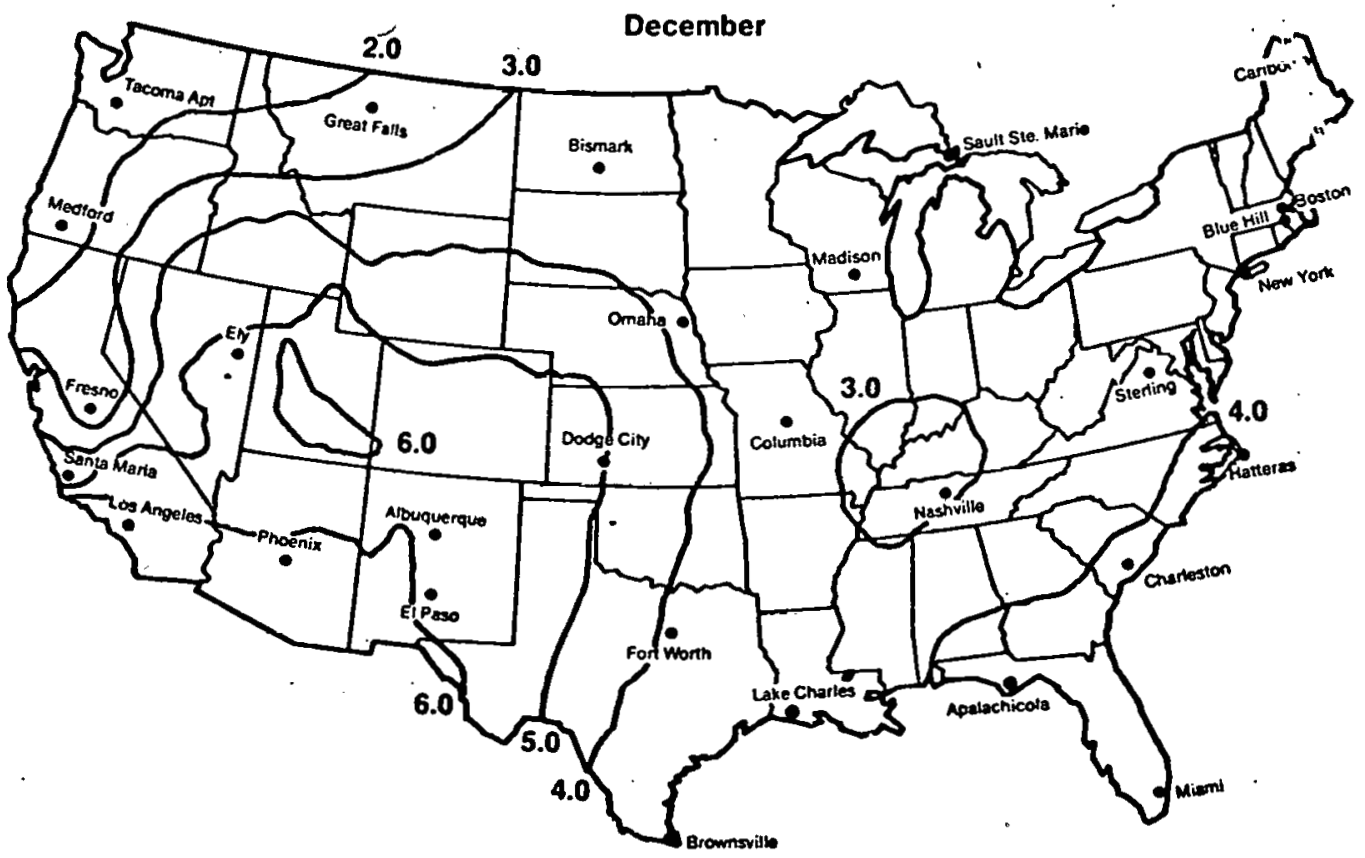

SOURCE: Boes, Eldon, et al. "Distribution of Direct and Tolal Solar Radiation Availabilities for the U.S.A." published by Sandia Laboratories (SAND76-0411). 
$-14-$

An estimate of the price one would pay for locating a solar powered industry in an area which did not receive much sunshine can only be made by comparing the sunshine received by various parts of the United States. For example, on the average, Phoenix, Arizona receives 67 percent more useable solar energy than does Cleveland, Ohio and 72 percent more than does Boston, Massachusetts. This means that all other things being equal, a photovoltaic system in Cleveland would have to be three times as large as uni in Phoenix to generate the same amount of energy and one in Boston would have to be nearly 3.6 times as large. 
3) The ideal solar photovoltaic powered industry should be able to tolerate both periodic and random losses of power.

The maximum average amount of hours the sun shines on any area of the United States is about 9.4 hours. This means that a solar photovoltaic powered industry located in this area would have no solar energy available on an average of 14.6 hours per day. In addition to this cyclical loss of power there is also a random loss of power which is caused mainly by cloud cover. The. minimum loss of available solar energy caused by this cloud cover is about 20 percent and the duration of the cloud cover can be anything from a few minutes to several days.

The cost of compensating for this cyclical and random loss of solar energy varies with the amount of compensation required. If a given industry requires electrical energy on a 24 hour basis then it would need enough solar photovoltaic generating capacity to meet its maximum daily requirements and enough extra capacity to provide energy for the storage devices needed to supply energy when the sun was not shining. The required storage capacity must be based on the amount of energy to be delivered on the shortest day of the year. In addition, there must be sufficient secondary storage to provide energy for as much as several days during those times when the area is under cloud cover for extended periods.

For areas which appear to be most suitable for solar photovoltaic powered industries, the shortest day has about 9 hours of sunshine. Industries Torated in thesc areas which-require a 24 hour power would have to have enough capacity to store 15 hours worth of eneray (plus losses) in 9 hours. This means they would need over 2.6 times the photovoltaic generating capacity as an industry which only needed energy when the sun shines. In addition these 
industries would need at least 15 hours worth of short term storage capacity and sufficient long term storage capacity to provide energy for those days when there was no sunshine available at all. Assuming a worst case of 4 days of no sunshine this would mean 96 hours of storage capacity.

Lead acid batteries are the only practical devices which are currently available for the storage of electrical energy. The lowest cost battery is the type which is used in automobiles and costs around $\$ 50$ per kwh (1976). These batteries are probably not useful for primary storage of photovoltaic energy because they lose over one half of their storage capacity after only 200 deep discharge-charge cycles.

A more suitable battery for energy storage would be the type used in industrial forklifts. These are capable of 2000 discharge-charge cycles and cost around $\$ 80 / \mathrm{kwh}$. Using this type of battery and assuming a 20 year life for the photovoltaic cells, the cost of storage for a 24 hour solar phiotovoltaic powered energy system would be approximately $\$ 296 / \mathrm{kwh}$. Th1s system would also require 2.67 times as much generattry capacity as a no storage system and at 50 cents per peak watt this would add $\$ 1444 / k$ wh of energy required by the industry. In addition, if a worst case cloud cover of 4 days was expected another $\$ 4800 / \mathrm{kwh}$ worth of secondary storage* would be required.

* This could be the $\$ 50 / k w h-200$ life cycle type of battery, since it would probably not be deep discharged more than 10 times per year. 


\section{PRIMARY METALS INDUSTRY}


The Primary Metals industrial group is conprised of seven. major industries. These are:

o. Steel

- Ferrous Castings

- Aluminum

- Copper

0 Lead

o Zinc

o Tin

Together these industries shipped a total of $\$ 116$ billion worth of products in 1978. Demand for the products of these industries comes from virtually every sector of the U.S. economy and consequently, the relative volume of shipments in these industries is a fairly good measure of the health of the nation's economy. The major consumers of Primary Metals products are the construction, automotive, transportation and capital equipment manufacturing industries.

Because of the cont inued pressure from imports, in recent years, the. Primary Metals industries have been operating well below capacity and this trend is expected to cont inue for at least the next few years. In 1977 and 1978 the United States imported $\$ 6.4$ and $\$ 10.5$ billion worth of metals. The bulk of this amount resulted from the importation of large amounts of alurinum, steel and copper.

In the next four years, the growth in demand for most of the Primary Metals is expected to closely follow that of the nation's. "real" GNP. This has averaged about 3.5 percent per annum since 1960. During the next four years the increase in volume for individual industries is expected t. percent for lead to 5.6 percent for aluminum. The major factors affecting demand in these industries will be a reduction in automobile size (this will have a negative effect on steel and lead and a positive effect on aluninum) 
and an increase in the cost of energy (this will effect all segments of the industry, but the major impact will be on the aluminum industry).

The Primary Metals Industries consumed approximately 12 percent of the total energy consumed in the United States and 23 percent of the electrical power. The following table lists the approximate amount of fuel required to produce 1 ton of five* of the seven primary metals.

Fuel Requirements*

$10^{6}$ BTU/ton of Metal

Steel

Aluminum

Copper

Zinc

Lead
37

280

80

60

27
1975 Fuel cost as à Percentage of Price

16.0

36.0

5.3

7.5

8.0

Data on the individual members of the Primary Metals industries is presented in the following sections. 


\section{STEEL}

In the last two years domestic shipments of steel mill products have been 91 and 97 million tons, respectively. The latter figure represents the third largest volume ever attained by the steel industry and the volume would have been even greater were it not for a record import level of 20 million tons. This figure represents a new record for import volume and the import share of the domestic market was approximately 17.5 percent. The net deficit in steel trade for 1978 was approximately 17.5 million tons, the highest on record. The dollar value of this deficit, $\$ 5.1$ billion, was also a new record, surpassing the $\$ 4.5$ billion recorded in 1977 .

The steel industry in the U.S. is composed of approximatelv 175 companies. of this total, about 30 are companies which operate electrically powered minimills (annual capacity of less than 500,000 tons of steel per mill). Most of the steel industry in the U.S. is located in the industrial complex surrounding the lower Great Lakes ports in Illinois, Indiana, Michigan, Ohio and Western Pennsylvania. There are also large steel mills in Northern New York, Eastern Pennsylvania, Eastern Maryland and the Birmingham District of Alabama.

For the years through 1985, steel consumption will be greatly affected by the trend toward building smaller cars. By 1985, the average weight of a passenger car is expected to decline by one-third from the 1975 value of 4000 pounds. However, the development of energy resources such as coal, and the revitalization of rail trallsport, including additions to rolling stock could do much to offset the expected flatness in steel consumption by the automotive sector. Even so, future steel consumption is projected by many experts to grow at a smaller rate than the approximate 2.5 percent annual rate experienced in the past. 


\section{PRODUCTION}

The term steel is used to denote many widely different alloys of iron. It is made from iron ore by removing the impurities and later adding substances such as manganese, chromium, nickel, tungsten, molybdenum and vanadium to produce alloys with properties which make them suitable for specific uses. Moșt steels also contain small percentages of carburi (0.04-2.5 percent).

The first step in the steel production process is the minimy of the iron Ui e. About 91 percent of the iron mined in the U.S. comes from open pit mines, with the balance coming from underground mines. Before being shipped to the smelter, most of this iron ore is subjected lo beneficiation operations to reduce transportation and smeltering costs. Commonly used beneficiation techniques include crushing, screening and the separation of iron particles from waste material by gravity, flotation or magnetic means.

The next step in the steel production process is the roasting of the iron ore in a blasl rurnace. This step is perfurmed primarily to remove water fruịi the ore. The metallic iron obtained from this process is called piy irun.

Currently, there are three methods used to transform pig iron into steel. These are the:

- Open hearth furnace method;

- Basic oxygen furnace method;

- Electric furnace melhod.

Before the introduction of the basic oxygen furnace in 1954, the open hearth furnace was responsible for 90 percent of the steel produced in the U.S. The open hearth furrace is a long shallow hath (or hearth) into. which a charge of pit iron, scrap iron, and iron ore is placed. The charge is then heated from above by a hot gaseous fuel which contains an excess of air. The oxygen in this air is used to oxidize the impurities in the hearth's charge. 
Typically, about 8 hours are required to complete this oxidation process.

Unce the process is complete the molten steel is poured from the hearth and a new charge is added. Compared to the other methods used to refine pig iron into steel, the open hearth furnace is relatively inefficient and its use is declining.

The basic oxygen furnace accounts for the bulk of the total production of steel in the U.S. The basic oxygen process utilizes:--8

"a cylindrical furnace with a basic linina (composed mainly of magnesium and calcium oxides). A typical furnace is charged with 80 tons of scrap iron, 200 tons of molten pig iron, and 18 tóns of limestone (to form slag), and operates under computer control. A jet of high-purity ( 99.5 percent) oxygen at 140-180 pounds pressure per square inch is directed vertically through a water-cooled lance, ... to a point 4 to 8 feet below the surface of the white-hot, molten charge. The reaction produces a vigorous boiling action that reaches all parts of the charge ... The entire steel-making cycle is completed in one hour or less -- much faster than the average heat time for open-hearth furnaces ... The steel produced is of extremely high and uniform quality. The basic oxygen process, because of its speed, efficiency and the high quality of its product, is rapidiy increasing in importance relative to the open-hearth process, rising from 6 percent of total steel production in 1962 to well over half the production in 1975"

The third type of furnace used to produce steel from pig iron is the electric furnace. The electric furnace is normally used to make alloy steels from which such articles as files, drills, knives, razor blades, etc. are made. The cost of electric power limits the use of electric furnaces to manufacturers in areas where a reliable source of scrap iron is more readily available and cheaper than pig iron. 


\section{CAPITAL COSTS}

The capital costs of establishing a modern iron ore mining operation are high. Most projects are designed to produce 3 million to 10 million tons of iron ore products per year and require a $\$ 100$ to $\$ 400$ million dollar initial investment. For individual projects, capital costs per annual ton of product ranged (in 1975) from $\$ 35$ to $\$ 55$ and averaged about $\$ 13$.

The capital costs of new steel making facilities in 1975 was in the $\$ 250$ to $\$ 600$ per annual ton ranqe, depending on location, scale of production and type of operation. The most efficient steel plants are intearated plants with annual capacities of over 2 mrition torls. The eost of construrtinn nf one of these plants in 1975 was over $\$ 500$ million. The high capital rnst of integrated steel plants has made the smaller scrap-melting electric furnace plants more economic. The minimum economic size of an electric furnace is 500,000 tons per year. 


\section{ENERGY}

The domestic steel industry uses about 5 percent of the total energy consumed in the U.S. The energy consumption per ton of end product is lower for steel than for most competitive materials, but the total anount of steel ut ilized in the U.S. economy is higher.

Recently, for the domestic steel industry as a whole, the energy consumption was about $37 *$ million BTU per ton of steel shipped. The 37 million BTU energy figure represents the total used in the various steelmaking steps including ore agglomeration, cokemaking and ore reduction, steel melting and casting, primary conversion, and finishing operations. The breakdown of this energy consumption by components is given in the following table.

\section{USA STEEL INDUSTRY ENERGY REQUIREMENTS}

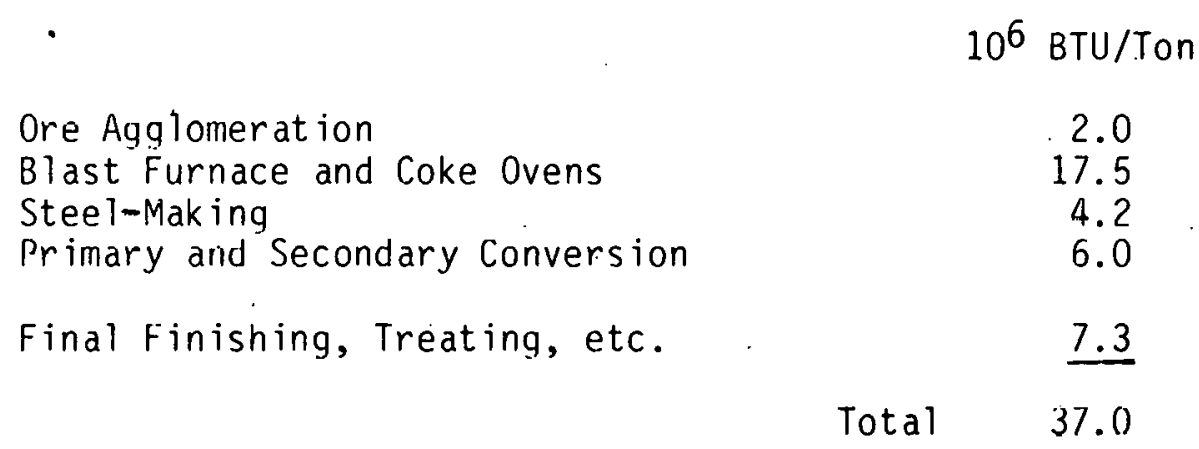

* This is a weighted average of energy requirements of the open hearth, basic oxygen furnace and electric furnace processes for making steel. 
The energy required for the ore agglomerating stage is a relatively small part of the total energy required, amounting to about 5 percent. The next major stage, the blast-furnace reduction of the iron oxide to metallic iron, requires about 47 percent of the total energy. In the third major stage, steelmaking, varying amounts of energy are consumed depending on whether the steel is produced in an open hearth furnace, in a basic-oxygen furnace, or in an electric furnace. The energy consumed in the open hearth furnace and the basic oxygen furnace is about the same and amounts to about 1.6 million BTU per ton of steel produced. Whereas the energy consumed in an electric furnace amounts to about $7.4^{\star}$ million BTU/Ton of steel produced. The electrical energy consumption in an average electric furnace is $450 \mathrm{Kwh}$. The weighted average of the energy consumed in the steelmaking stage is 11 percent of the total energy consumed. The next stage in the steel production process is the reheating and primary and secondary rolling stage. Ihe weighled average of the cnergy consumed in this stage is. 16 percent nf the total. The remaining 21 percent of the energy is consumed in the tillishing, furging, trcating and coating processes. and in the shops, offices and miscellaneous plant utilities.

* The energy requirements for electric furnaces and the other two methods of producing steel are not directly comparable, since the electric furnace uses a charge which is approximately 98 percent scrap and 2 percent pig iron whereas the other two use a charge which is closer to 30 percent scrap and 70 percent pig iron. Since most of the electric furnaces charge is already in metallic form, it does not require an ore agglomerating and blast furnace stage and therefore, does not need to supply the 21.9 million BTU/Ton which is consumed in these stages. 


\section{FERROUS CASTINGS}

In the last two years, domestic shipments of ferrous castings have amounted to 17.5 and 18.5 million tons, respectively. During this same time period the U.S. has had a positive balance of trade in ferrous castings of more than 2 to 1.

The ferrous castings industry is composed of large foundries.captive to other industries (such as automobile manufacturers), small independent jobbing foundries and manufacturers of various types of cast iron and cast steel products. The U.S. foundry industry is composed of approximately 1760 foundries. These foundries range in size from small 2 to 3 man operations to large multimillion dollar operations, employing several thousand people. The pattern of geographical distribution of the foundry industry, in general, is the same as that of the steel industry. Like the steel industry most of the foundry industries capacity is located in the industrial complex surrounding the lower Great Lakes ports in Illinois, Indiana, Michigan, Ohio and Western Pennsylvania. There is also considerable foundry capacity located in New York, New Jersey, New England and the South Atlantic States.

The main products of the foundry industry are gray, malleable and ductile iron castings and steel castings. Products made from these ferrous castings include large valves, fittings and machinery parts for farm equipment, automobiles, earthmoving and mining equipment and electrical generating equipment.

In the future the ferrous castings industry is expected to experience modest growth in its domestic market. This. growth will result primarily from improvements in foundry facilities and automation techniques which will help. to make ferrous castings more competitive with other modes of fabrication of 
machinery parts. The projected growth rate for the castings industry is 3.5 percent through 1983 .

The production, costs and energy requirements of the ferrous casting. industry are very similar to those of the steel industrv. 


\section{ALUMINUM}

In the last two years domestic production of aluminum has amounted to 6.315 million and 6.7125 million tons, respectively. The level of aluminum imports in 1977 and 1978 was 0.98 million and 1 million, tons, respectively.

In 1975 there were 12 domestic firms producing primary aluminum. These firms were primarily located in the states of Washington, Texas, Kentucky, Louisiana, Tennessee, Indiana, New York and Ohio.

The aluminum industry is divided into a primary production segment which produces refined aluminum from bauxite and alumina, * and a secondary production segment which produces refined aluminum from recycled aluminum scrap. In 1978 the primary production segment produced 4.8 million tons while the secondary segment accounted for 1.6 million tons. Ninety percent of the bauxite required by the primary production segment is obtained from imports, whereas, almost all of the scrap used by the secondary segment is obtained from domestic sources. In 1978 the secondary aluminum industry accounted for about 22 percent of the total domestic aluminum supply. This percentage is expected to grow in the future because of the rapidly increasing interest in recycling and municipd solid waste processing. Recycling of aluminum products has value both for the conservation of primary aluminum and for energy savings. Smelting of secondary aluminum saves 95 percent of the energy required to produce aluminum from bauxite.

* Alumina (aluminum oxide) is an aluminum production raw material which is derived from bauxite. In recent years many of the bauxite producing countries have developed their own bauxite to alumina facilities and as a result, many of them have begun shipping alumina to the U.S. rather than bauxite. 
For the years through 1983, the aluminum industry is expected to grow at a faster rate than the overall economy. It is expected that the industry will grow at a compound rate of 5.6 percent during these years. This growth will be due primarily to increased penetration of aluminum into the transportation and the container and packaging markets. Because of the growing emphas is on energy savings it is anticipated that pruduction of the 1983 model cars will cause a doubling of aluminum usage in the automotive industry. Aluminum's share of the car market is expected to reach 75 percent by 1983 (up from 55 percent in 1978). Arrother area which may consume significant amounts of aluminum is the solar heat market, slice lie average solar heater requires approximately 1,000 pounds of aluminum. 
PRODUCTION

The production of aluminum from bauxite is a three step process. "The' first'step involves the mining of bauxite ore. Bauxite is a compound which consists mainly of anhydrous aluminum oxide $\left(\mathrm{Al}_{2} \mathrm{O}_{3}\right)$ and hydrated aluminum oxide $\left(\mathrm{Al}_{3} \mathrm{O}_{2} \cdot \mathrm{H}_{2} \mathrm{O}\right)$ and $\left.\mathrm{AL}_{3} \mathrm{O}_{2} \cdot 3 \mathrm{H}_{2} \mathrm{O}\right)$. It usually requires approximately 4.5 tons of average grade bauxite to produce 1 ton of aluminum. Since the U.S. has only a small reserve of bauxite, over 90 percent of U.S. bauxite requirements is imported. The major countries of origin for this bauxite are Jamaica ( 53 percent), Guinea (17 percent) and Surinam (16. percent). Bauxite production in the U.S. is centered mainly in Arkansas, with some output also coming from Alabama and Georgia.

The next step in the aluminum production process is the conversion of bauxite to alumina (aluminum oxide)....8
"Alumina is derived from bauxite by leaching with caustic soda followed by precipitation of hydrated aluminum oxide by hydrolys is and seeding of the solution. The alumina hydrate is then washed, filtered and calcined to remove water and obtain the anhydrous oxide"

It usually requires approximately 2.25 tons of average grade bauxite to produce 1 ton of alumina.

While most of the alumina which is used by U.S. aluminum producers is produced domestically, in recent years there has been an increasing trend towards the bauxite mining countries producing the alumina themselves and shipping alumina to the U.S. rather than raw bauxite ore.. In the U.S., imported alumina accounted for approximately 36 percent of the aluminum produced. The major countries of origin for imported alumina are Australia (71 percent), Jamaica (19 percent) and Surinam ( 8 percent). 
The final step in the aluminum production process is the conversion of alumina to metallic aluminum. In the U.S., this is normally done using an electrolytic process called the Hall process. - 8

"A typical cell for this process consists of a rectangular steel shell, lined with insulating brick and block carbon. The cell holds a molten cryolite-aluminum electrolyte, commonly called the 'bath'. The carbon bottom is covered by a pad of molten aluminum, and serves as the cathode. The anodes are prebaked carbon blocks suspended in the electrolyte. The cathodic current is collected from the carbon bottom of fmbedued steel liaths that protrude through the shell to connect with the calhode bus. During electrolysis, aluminum is deposited in the metal pad ... At 24-48 hour intervals, aluminum is tapped from the ceil by a siphon. The process requires large amounts of electric power (from 4 to $5 \%$ of total U.S. production)..." 
CAPITAL COSTS

The cost of building aluminum production facilities varies considerably depending upon location, availability of labor and infrastructure and the type of plant and process used. Typical capital costs for new aluminum production in 1974 are illustrated in the following table.

\begin{tabular}{|c|c|c|c|}
\hline Product & $\begin{array}{l}\text { Average Short } \\
\text { Tons Required }\end{array}$ & $\begin{array}{c}\text { Capital Costs } \\
\text { Per Ton of } \\
\text { Product } \\
\end{array}$ & $\begin{array}{l}\text { Capital Costs } \\
\text { Per Ton of } \\
\text { Aluminum } \\
\end{array}$ \\
\hline $\begin{array}{l}\text { Bauxite } \\
\text { Alumina } \\
\text { Primary Aluminum }\end{array}$ & $\begin{array}{l}4.5 \\
2 \\
1\end{array}$ & $\begin{array}{r}\$ \quad 45 \\
400 \\
1,500\end{array}$ & $\begin{array}{r}\$ 200 \\
800 \\
1,500\end{array}$ \\
\hline
\end{tabular}

In addition to the plant capital costs, about two kilowatts of electric generating capacity is required to produce 1 ton of aluminum a year. The estimated cost for new power plants in 1974 was $\$ 300$ to $\$ 600$ per kilowatt. Added to the other capital costs (excluding bauxite mines since most bauxite is imported) this yields a total of $\$ 2,600$ to $\$ 2,900$ per ton of annual capacity for new aluminum production capacity.

The costs of aluminum production also varied widely, depending on the type of bauxite used, on the types of alumina and aluminum plants and on power, labor, raw material and environmental costs. Costs (excluding profit) of aluminum production in 1974 are illustrated in the following table.

\begin{tabular}{|c|c|c|c|}
\hline Product & $\begin{array}{l}\text { Average short } \\
\text { Tons Required }\end{array}$ & $\begin{array}{c}\text { Capital Costs } \\
\text { Per Ton of } \\
\text { Product }\end{array}$ & $\begin{array}{l}\text { Capital Costs } \\
\text { Per Ton of } \\
\text { Aluminum }\end{array}$ \\
\hline $\begin{array}{l}\text { Bauxite } \\
\text { Alumina } \\
\text { Primary Aluminum }\end{array}$ & $\begin{array}{l}4.5 \\
2 \\
1\end{array}$ & $\begin{array}{r}5-25 \\
45-80 \\
300-600\end{array}$ & $\begin{array}{r}\$ 22-110 \\
90-160 \\
300-600 \\
\$ 412-870\end{array}$ \\
\hline
\end{tabular}




\section{ENERGY}

About 60 percent of the total energy used by the aluminum industry is in the form of electrical power for the smelting process. Over the past three decades, the amount of electrical power required for smelting aluminum has been cut nearly in half. Prior to World War II, $12 \mathrm{kwh}$ of electricity were nceded to produre one pound of aluminum. Today the average smelters use 8 $k$ wh, while some of the more efflrterly plants are able to produce aluminum using as little as $6.5 \mathrm{kwh}$ of electricity per pound. In 1976 a new process was introduced (the Alcoa Smelting Process) which, its developers claim, can produce aluminum using only $4.5 \mathrm{kwh}$ per pound of aluminum produced. Traditionally, the aluminum industry has derived much of its energy from hydroelectric sources, and has generated a large percentage of its own electric power requirement.

The aluminum industry is especially vulnerable lo a loss of clectrical power. If the power is lost suddenly, the aluminum production cells may freeze in 30 minutes and it may take several months to reach maximum production again after power is restored. 
COPPER

In the last two years, domestic production of copper products has been 1.87. and 1.98 million tons, respectively. Since 1975 U.S. copper producers have come under increasing pressure from foreign imports. In 1978, copper imports reached 490,000 tons, up 25 percent from 1977.

The principal copper producing states in the U.S. are Arizona, Ut ah, New Mexico, Montana, Nevada and Michigan. In 1974 these states had a total refinery capacity of 2.9 million tons, of which approximately 88 percent was electrolytic refining capacity and 12 percent was fire-refining capacity. About 47 percent of the domestic electrolytic refining capacity was accounted for by 6 refineries in New York, New Jersey and Maryland. The remaining 53 percent was accounted for by Arizona with two plants and by Missouri, Montana, Texas, Ut ah and Washington with one each.

In the near future (through 1980) domestic consumption of copper is expected to remain relatively flat, after 1980 it is expected to increase at an annual rate of between 3-3.5 percent. While the long range outlook is for copper consumption growth, prospects for domestic production are not as good. Both the domestic and world copper industry have suffered from relatively low prices and overall excess supply since 1975. This situation has led to poor or non-existant profits and the suspension or severe curtailment of new capacity, development, research and exploration. New capacity is expected to increase only slightly between 1979 and 1983. 
PRODUCTION

The major copper ores in the world are in the form of sulfides such as chalcopyite $\left(\mathrm{CuFeS}_{2}\right)$ and charcocite $\left(\mathrm{Cu}_{2} \mathrm{~S}\right)$. With the exception of the rich Zambian and Katangan sulfide ores which can contain up to 5 percent copper, most ores have a copper content of around 1 percent or less. Typical U.S. ores $r$ ange in copper content from about 0.5 percent to 1.0 percent, although one Arizona mine was reported lu. pr duce ore averaging 3.75 persent. copper.

Open pit mining accounts for over 89 percent of the ore produced in the United States. After drilling and blasting, the broken ore is transported to a beneficiation plant where it is crushed and ground. The bulk of the copper ores in the United States are beneficiated using a froth flotation technique. Typically over 90 percent of the copper is recovered in the process and the concentrate contains between 15 percent and 35 percerit copper.

After beneficiation, the concentrate is rodsted in a furnacc at a temperature below the fusion point of the ore, to drive of $f$ the moisture and remove part of the sulfur as sulfur dioxide. The remaining mixture, called calcine, consists mainly of $\mathrm{Cu}_{2} \mathrm{~S}, \mathrm{FeS}, \mathrm{FeO}$ and $\mathrm{SiO}_{2}$. This mixture is smelted by mixing it with limestone (which serves as a flux) and heating it above its melting point.

The Cu2 5 which rullains after smolting is called matte. Reduction of the matte is typically accomplished in a converter by blowing air through the molten material. The copper obtained in this way has a characteristic appearance due to the air blisters which it contains, and is called blister copper. This impure copper is cast into large plates, which are used as anodes in the electrolytic purification of the netal. Thin sheets of pure copper serve as 
$-35$

the cathodes as electrolysis proceeds. Gold and silver in the anodes do not oxidize but fall to the bottom of the electrolytic cell as anode mud, "along with bits of slag and $\mathrm{Cu}_{2} \mathrm{O}$. Silver, gold, and the platinum group metals are recovered from the anode mud as valuable byproducts. The metals more active than copper, such as zinc and iron, are oxidized at the anode and their cations pass into an average purity of 99.955 percent. The value of the precious metals recovered from the anode mud is often sufficient to pay the cost of the electrolytic refining. 
COSTS

Copper production is considered to be a capital-intensive industry requiring at least $\$ 4,500$ per ton of new capacity for facilities from mining through refining. Copper production costs vary depending upon the location and physical characteristics of the ore deposit. For a representative large open pit copper operation the distribution of direct operating costs in terms of percentages of the price of copper, are estimated t.l be 15 percent for mining, 25 percent for ore beneficiaries and 25 percent for freight, smelting and refining. The remaining 35 percent is required for items such as discovery, development, taxes, inarketing and general overhead including profit. 


\section{ENERGY}

The energy consumed in a typical* copper production process is given in the following table.

\section{Diesel Fuel. Natural Gas $10^{6}$ BTU/Ton $10^{6}$ BTU/Ton}

Mining

Concentration

Dump Leach

Smelting

Refining

Total

$$
4.8
$$
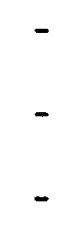

$\therefore$

4.8

$$
\text { Electric Power }
$$

Kwh/Ton

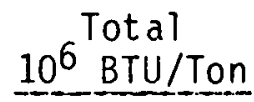

400

9.5

24.2

15.0

24.2

21.0

300

7.91

80.81

* A large integrated open-pit copper facility in the Southwestern U.S. 
In mining, diesel fuel is mainly consumed by haulage trucks. These trucks haul both ore and waste. Consequentiy, the tonnage is strongly dependent on the stripping ratio. The figure in the table is based on a rat io of 2.3 tons of waste per ton of ore. The tonnage hauled also depends on the ore grade, and on the recovery in concentrating and smelting. Fuel consumption per ton of material hauled is also dependent on the average distance per round trip, on the-feet of lift, and on the type of vehicle used.

Electric power in the mine is mainly used for drilling and loading. In general, the trend in mining has been to electrically powered drills and shovels, and-to large diesel-electric trucks.

The main energy consumer in the concentrator operation is for wet grinding using electrically driven ball mills. The power requirement of a ball mill, per ton of ore, varies with the hardness of the ore. Of all the copper processing operations, concentrating is the chief enerqy consumer. This results from the need to crush and grind as much as 200 tons of ore per ton of copper produced.

The power consumed in the dump leaching operation is used for the most part to pump acidified water up to the dumps. From there it percolates down through the dump by gravity, picking up copper as it trickles down. When it arrives at the bottom, it typically contains $0.5-1.0 \mathrm{~g} / \mathrm{L} \mathrm{Cu}$. This operation actually consumes $7,000 \mathrm{Kwh}$ per ton of precipitate copper, since it only contributes about $20 \%$ of the total copper produced.

Smelting requircs 6-7 million BTU per ton of concentrate, or about 21 million BTU per ton of copper, to fire the dryer and reverberatory furnace. Electrical power for the smelting operation is mostly generated via waste heat boilers. 
Electrolytic refining is the least energy-intensive step in the copper production process. Main power consumption occurs due to the ohmic voltage drop through the electrolyte, electrode overpotential and buss bar losses. In sum, about $70 \%$ of all energy requirements in the copper production process occurs prior to smelting. These requirements vary with ore grade, stripping ratio, rock hardness, fineness of grind and copper content of dump leach liquor. 
LEAD

In the last two years domestic production of lead has been approximately 1.3 million tons each year. The lack of growth from 1977 to 1978 was due primarily to labor strikes, bad weather and fuel shortages. The lead industry is expected to recover in 1979 and domestic production is expected to increase about 2.9 percent. The level of refined lead imports in 1978 was approximately 230,000 tons, 15 percent below the 1977 value. This decline in imports represents a reversal of the trend since 1975 and lhis reversal is expected to cont inue in 1979.

The U.S. has the larqest reserves of lead in the world and is also the largest consumer of lead in the world. The largest lead producing area in the U.S. is located in Southeastern Missouri. The seven leading mines in the U.S. are located in Missouri and together they produce approximately 80 percent of domestic lead. The leading lead ore production states in order of production are Missouri ( 85 percent), Idaho ( 8 percent), Colorado ( 4 percent), and Utah (1 percent). The major lead smelters and refineries dre lucated in Missouri, Nebraska, Idaho, Montana and Texas.

The lead industry is divided into a primary production segment, which produces refined lead from lead ore, and a secondary production segment which produces refined lead from scrap lead. Secondary producers actively compete with primary producers, as scrap lead is virtually an ideal substitute for primary lead in certain applications. In recent years the production of primary lead has declined (it accounted for 38 percent of total refined lead production in 1978), but this trend is expected to reverse itself in 1979.

The United States has the most developed and efficient secondary lead production industry in the world. In 1977, an estimated 80 percent of al 1 
lead available for recycling was recycled (approximately 58 percent of all lead produced is technically recycleable).

The secondary lead industry is heavily dependent on the battery industry, both as a market and as a source of feed material. Batteries contribute about 75 percent of the total scrap lead recovered and battery manufacturers consume about 60 percent of the total secondary lead production. The battery scrap cycle is relatively closed as battery manufacturers and others accumulate and sell scrapped batteries to secondary smelters, which in turn recycle it as antimonial lead to sell back to the battery manufacturers.

The major consumers of lead in the U.S. are the manufacturers of batteries and the manufacturers of leaded gasoline. In 1978, lead consumption for battery manufacture amounted to an estimated 930,000 tons. This was off 1.6 percent from 1977 level and well below the recent historical growth rate of 5.3 percent. In 1978, lead consumption for tetraethyl lead (used in leaded gasoline) was approximately 195,000 tons, down 16 percent from the 1977 level. Lead is also used in ammunition, construction materials, solder and pigments. These uses consumed approximately 395,000 tons of lead in 1978, a level which was virtually unchanged from the 1977 level.

There are two conflicting trends which should govern the future demand for lead. One trend is driven by environmental and health regulations, and developments in the automobile battery market. The other trend is driven by the growth in the electric vehicles market and the energy storage market.

Lead usage in batteries will be adversely impacted by the proportionately greater production of smaller cars, which require a smaller, lighter battery and by the growing use of maintenance free batteries, which use less lead and last longer than the traditional battery. Lead consumption for tetraethy 1 
lead faces a potential 70 percent reduction over the next few years. This is due primarily to EPA regulations mandating a reduction of lead in gasoline.

The use of lead in electric vehicles and in energy storage systems can potentially have a significant impact on lead in the distant future. Assuming these applications become fairly widespread they could consume as much as 450,000 tons of lead annually. 
PRODUCTION

Room-and-pillar mines account for the bulk of the lead ore mined in the United States, and the principal lead ores mined in the United States typically contain 3 to $6 \%$ lead. After mining the lead ores are concentrated using a series of selective flotation processes to remove much of the waste materials and a large part of the zinc sulfide which is usually associated with lead ores. The concentrated ore is then roasted in air (called sintering) to convert most of the lead sulfide to lead oxide $(\mathrm{PbO})$. After sintering the lead oxide mixture is mixed with coke and sent to a blast furnace for reduction. The blast furnace operation requires 0.3 tons of coke per ton of lead produced. The lead obtained from the blast furnace contains copper, antimony, arsenic, bismuth, gold and silver.

The crude lead which comes from the blast furnace is sent to the refiner where it is melted and stirred to bring about the oxidation of antimony, arsenic and bismuth. The oxides of these metals rise to the surface and the. molten lead is drained of $f$ for further refining. The final refining step in lead production is normally performed using the Parkes process (used when significant amounts of silver are mixed with the crude lead) or the Betts process.

The Parkes process is one in which the silver is extracted from the fused lead by the use of molten zinc.--8

"Ihe lead is fused and thoroughly mixed with a small quantity of zinc ( $1-2 \%$ of the quantity of lead). Lead and zinc are immiscible. Most of the silver leaves the lead and dissolves in the zinc. When mixing is stopped, the zinc rises to the surface of the lead and solidifies. The zinc-silver alloy is.removed from the lead. and the more volatile zinc is separated from the silver by distillation." 
Normally this procedures must be performed several times in order to completely separate all of the silver from the lead.

The Betts Process is:--8

"An electrolytic process for removing impurities from lead, in which pure lead is deposited on a th in cathode of pure lead, from an anode containing as much as $10 \%$ of silver, gold, bismuth, copper, antimony, arsenic, selenium, and other impurities. The electrolyte is lead fluosidic acidfluosilicate $\left(\mathrm{PbSiF}_{6}\right)$ and fluosilicic acid $\left(\mathrm{H}_{2} \mathrm{SiF}_{6}\right)$. The scrap anodes and the residues of impurities associated with thell are either recast into anodes or treated to recover anițmonial lead, silver, gold, bismuth, etc." 
COSTS

The capital costs of a new lead production mine includes costs: for initial development, mining equipment, surface plant, working capital and a contingency al lowance. These costs vary depending upon the size of the operation and the type of mining techniques used. The variations of these costs are illustrated by the following table (for 1974).

Type of Operation

150 ton/day cut-and-fill mine 2000 ton/day cut-and-fill mine 250 ton/day room-and-pillar mine $5000 \mathrm{ton} /$ day room-and-pillar mine
Total Costs

$\$ 1.04$ million

6.53 million

1.47 milion

4.30 million

The operating costs of a lead mine also vary depending on the type of mining technique used and the size of the operation. These variations are illustrated by the following table.

Type of Operation

150 ton/day cut-and-fill mine 2000 ton/day cut-and fill mine

250 ton/day room-and-pillar mine

5000 ton/day room-and-pillar mine
Cost per Ton of Lead

$$
\$ 29.00
$$

19.00

9.20

3.70

The estimated total capital investment for a new lead production smelter and refinery in 1974 ranged from $\$ 3$ million for a 600 ton/day plant to $\$ 13.7$ million for a 6800 ton/day plant. Estimates for the operating costs of these plants ranged from $\$ 4.50$ per ton for a 600 ton/day plant to about $\$ 2.10$ per ton for a 6800 ton/day plant. 
ENERGY

The energy required to produce 1 ton of lead (including mining, concentration, smelting and refining) is approximately 27 million BTU, a value which is the lowest of any of the major metals. The per-ton energy requirements for lead are about one-fourth that for refined copper, and less than one-half that of zinc. About one-third. of the encrgy required for lead production-is used in ore mining and beneficiation. The energy requirements for a typical lead smelting operation are given in the following table.

\section{Lead Smelt ing}

Fuel Requirements $10^{6}$ BTU/Ton $\quad 5.14$

Electric Power Requirements Kwh/Ton $\quad 46.9$

The remaining 14 million BTU of energy is consumed in the lead refining process. If the electrolytic refining process is used this amounts to approximately $1320 \mathrm{Kwh} / \mathrm{ton}$ of metal produced. 
$\underline{\text { ZINC }}$

In the last two years, domestic production of zinc has been 501,000 and 470,000 tons, respectively. The decline in production from 1977 to 1978 was due primarily to a flat consumption level coupled with a heavy influx of lower-priced imports and a high level of producer, consumer and merchant inventories. The level of zinc imports in 1978 increased 15 percent to a near record of 640,000 tons (the record is the 695,000 tons imported in 1976.)

The United States is a major consumer of zinc, using about one quarter of the total world supply in 1974. However, net U.S. production of zinc amounts to only about 8 percent of the world supply. Zinc deposits in the United States extend from Maine through the Appalachian and West through the Mississippi into the Rocky Mountain states. The major zinc smelters and refineries are located in Pennsylvania, Oklahoma, Ililinois, Idaho and Texas. U.S. reserves of zinc have been estimated at 30 million short tons. In 1974, 17 states produced zinc, with New York, Missouri, Tennessee, Colorado and Idaho contributing 72 percent of the total domestic output.

The primary consumers of zinc are the galvanized steel manufacturers. In 1978, steel manufacturers consumed approxilialely 475,000 tons of zinc. This represented 43 percent of the zinc consurned in the U.S. that year. The second major area of zinc consumption was in die-cast applications. Zinc use in die-casting consumed about 365,000 tons in 1978. Brass manufacturers were the third major user of zinc in 1978, consuming approximately 150,000 tons that year.

Through 1983 zinc consumption is expected to grow at an annual rate of between 3 to 3.5 percent. This growth will largely reflect the trend towards increased corrosion protection (galvanizing) by manufacturers in the durable 
goods and automotive areas. Zinc use in die-casting is expected to decline through 1981 and then rebound to about 380,000 tons by 1983. This expected growth in die-casting applications will be caused primarily by an increase in the cost of zinc's major competitors - plastic and aluminum - due to increased fossil fuels costs. 


\section{PRODUCTION}

The principal mining methods used in zinc production are room-and-pillar, cut and fill and square set. The cycle of operations in mining consists of drilling, blasting and removing broken rock. Compressed air drills are normally used in the drilling step and electric, compressed-air or diesel shoveling and loading machines are normally used for handling the broken ore. Typical domestic zinc ores range in zinc content from 3 to $10 \%$, with $5 \%$ being the average.

The separation of metallic zinc from its ore normally begins with the milling of the ore to prepare a zinc ore concentrate. The reduction of zinc ores and concentrates to metallic zinc is accomplished by electrolytic deposition from a solution or by distillation in retorts or furnaces. For either method the zinc concentrate is first roasted to eliminate most of the sulfur and produce an impure zinc oxide called roasted concentrates or calcines.

In the electrolytic zinc reduction process, the roasted zinc concentrate is first leached with dilute sulfuric acid to form a zinc sulfate solution. This solútion is then purified and piped to electrolytic cells, where the zinc is electro-deposited on aluminum rathodes. Periodicdlly these cathodes are removed from the solution, and stripped of the zinc, which is then melted in a , furnace and cast into slab form.

Zinc concentrates which are shipped to electrolytic plants normally contain lead, gold and silver. As the zinc is processed, the electrolytic tank becomes enriched in these metals and the residue from these tanks is often more valuable than the zinc which is produced.

The reduction of $z$ inc by distillation can be performed using one of three types of plants. These are batch retorts, horizontal retorts, and cont inuous 
vertical retorts. All three types employ coal or coke as the reducing agent. These retorts produce metallic zinc by first vaporizing the zinc contained in the ores and concentrates and then passing this zinc vapor into condensers where the zinc is collected as liquid metal ready for casting into slab form. Zinc produced by distillation normally must go through a refining stage in order to obtain the same purily as electrolytically prodused zinc.

Refining by distillation is accomplished in vertical fractionating columns, which separate the impurities from the zinc in a manner similar to the way in which the diffcrent petroleum fractions in crude oil are separated. 
COSTS

Capital costs for zinc mining, smeltering and refining operations are assumed to be similar to those for lead.

In 1974 the annual operating costs for a typical domestic zinc mine ranged from $\$ 4$ per ton to $\$ 9$ per ton of $z$ inc ore and smelting charges varied from $\$ 90$ to $\$ 150$ per ton of zinc concentrate. Flectrolytic zinc production costs for a typical 120,000 ton per year refining plant were estimated at $\$ 115$ per ton of slab zinc.

The cost of transporting zinc ores and concentrates from mining areas to refining plants is a major expense in zinc production. In 1974 the cost of transporting zinc ore and concentrates, based on a distance of 600 to 1000 miles ranged from $\$ 15$ to $\$ 20$ per ton. The location of zinc refineries in five states compared with mine production in 17 states necessitates long shipping distances for most producers. In addition, the costs of transporting refined slab zinc from refineries in southwestern and Rocky Mountain areas to the Eastern and Midwestern consuming areas add another $\$ 25$ to $\$ 50$ per ton to the cost of zinc. 


\section{ENERGY}

The following table lists the energy requirements of the three different zinc refining processes.

Types of Zinc Refining Processes

\section{Vertical Retort Electrothermic Electrolytic}

Fue 1 Requircments.

$10^{6}$ BTU/Ton

Waste Heat Credit

$10^{6}$ BTU/Ton

Electric Energy

Kwh/Ton

Energy Equivalent of

Electricity Consumed

$10^{6}$ BTU/Ton

( $1 \mathrm{Kwh}=10,600$ BTU)

Net Energy Requirement

$10^{6}$ BTU/Ton
39.8

88.4

2.9

6.9

231

2606

3085

2.5

27.6

32.7

33.9

41.2

25.8

The total amount of energy required to produce a ton of zinc from the inining of the ore to the final refining stage varies depending on what type of refining process is used. The electrolytic process rcquires the least amount of energy ( 60 million BTU), followed by the vertical retort process (65 million BTU) and the electrothermic process (72 million BTU). 
TIN

In the last two years, the U.S. consumed $t$ in at the rate of 66.9 and 67.5 thousand tons, respectively. Of this amount only 24.3 and 25 thousand tons were produced domestically. Most U.S. tin is imported from countries in Southeast Asia. These are Malaysia (57 percent), Thailand (16 percent) and Indonesia (11 percent). In 1978, there was only one domestic tin smelter in operation (located in Texas City, Texas). The company imports all of its tin ores and $t$ in concentrates (mainly from Bolivia) and its 1978 output of refined tin was about 7 thousand tons.

The secondary production segment of the U.S. t in industry accounts for over 70 percent of domestically produced $t$ in. Until recently, secondary tin production has been declining (from 25,000 tons in 1967 to a low of 16,953 tons in 1977), however, the price of tin has almost quadrupled since 1970 and as a result, the recovery of tin from scrap has become economically attractive again.

Tinplate for cans is the largest market for tin (30 percent of the $t$ in consumed is used by this market) although in recent years its use in this market has declined from 32,300 tons in 1968 to an estimated 20,200 tons in 1978. The second major market for $t$ in is the solder industry. This use accounts for 29 percent of $t$ in consumption. The third major market for $t$ in is in the manufacture of bronzes and brasses. This market accounts for 14 percent of the tin consumed.

Since the U.S. depends upon foreign sources for the majority of its primary $t$ in and since this tin reaches this country ready to use, an analys is of tin production methods, costs and energy uses would not serve much purpose with in the context of this report. 
PRIMARY METALS AND THE IDEAL CRITERIA 
Currently, none of the Primary Metals Industries measure-up well with respect to the criteria for an ideal solar photovoltaic powered industry. This is due primarily to the way that the industries operate. Because of the high capital costs associated with these industries and the availability of energy sources on a 24 hour basis, these industries have been configured to operate on as close to a 24 hour basis as possible. Consequently, in order to use solar photovoltaic energy in these industries as they are currently configured, extensive energy storage facilities would be required. This need for energy storage violates the third element of the ideal criteria.

A more detailed assessment of each of the industries with respect to the ideal criteria is given in the following paragraphs. 
ALUMINUM

The major user of electrical power among the Primary Metals group is the aluminum industry. In 1978, the domestic aluminum industry consumed in excess of 76.8 billion kwh of electrical energy in producing 48 million tons of primary aluminum. The voltage requirement for aluminum production is 5 to 6 volts $D C$ and the current required to produce one pound of aluminum is in excess of 1000 amperes. Because of the tremendous amount of electricity required in aluminum production, most aluminum plants are located near rivers where large darns and electric generating facilities are available.

The aluminum industry is extremely vulnerable to a loss of electrical power. If the power to a potiine is lost suddenly, the aluminum production cells may freeze and it may take several months to reach maximum production in the entire line after power is restored.

with respect to the elements of the criteria for the ideal photovoltaic powered industry:

1) Aluminum qualifies as an industry which can use DC voltage for most of its electrical power requirements.

2) Since most of the raw materials for aluminum production - bauxite and alumina - are imported (primarily from Jamaica, Guinea, Surinam and Australia) there is no reason why aluminum production plants cannot be located in the southwestern parts of the U.S. or in Southern California.

3) Since the present methods of producing aluminum are extremely sensitive to loss of power, the aluninum industry can tolerate neither a periudic nor a random loss of power due to a lack of sunshine. If solar photovoltaic eneray were used to power an aluminum production plant cxtensive slorage would be required. 


\section{STEEL}

In 1978 the domestic steel industry consumed approximately 41 billion kwh of electrical energy in the production of 135 million tons of raw steel. Most of this electricity was $A C$ and much of its was consumed in electric furnaces. The U.S. iron and steel industry is centered around the Great Lakes and the economics of water transportation of iron ore versus land transportation will probably insure that the Great Lakes region will remain the Ilajor center of iron and steel making for the fureseeablc future. Alsn because 1ron and steel plants are so capital intensive it is usually desirable to operate them on a 24 hour basis whenever demand for iron and steel products allow it. With respect to the elements of the criteria for an ideal solar photuvoltaic powered industry:

1) Although most of the electric energy currently being consumed by the steel industry is $A C$, there are no inherent technological reasons why DC cannot. be used.

2). Because most of the U.S. supply of iron ore is located in the Great - Lakes region and land transportation costs are relatively high it does not appear feasible to locate 'much of the U.S.'s steel making capacity in areas with high solar insolation. However, there is a possibility that plants using electric furnaces lu iefine scrap iron and iteel can be located in those areas of the southwest and Southern California which have sufficient supplies of scrap.

3) The high capital costs of steel production plants, dictate that they be utilized as close to full time (i.e., 24 huurs a day) as possible. If solar photovoltaic energy were used to power these plants, extensive electrical storage capacity would be required. 
COPPER

In 1978, the domestic copper industry consumed approximately 9.82 billion kwh of electrical energy in the production of 1.98 million tons of copper. Most of this copper (approximately 88 percent) was produced using electrolytic refining methods and about 47 percent of this electrolytic refining capacity was located on the East Coast. The remaining 53 percent was located in Arizona, Missouri, Montana, Texas, Utah and Washington. The principal copper producing states are Arizona, Utah, New.Mexico, Montana, Nevada, and Michigan.

With respect to the elements of the criteria for an ideal solar photovoltaic powered industry:

1) Most of the electrical energy which is consumed in the production of copper is $A C$ and is used mainly to drive motors in drills, shovels, grinders, pumps and air blowers. Approximately 14 percent of the electrical energy is consumed in DC form as a part. of the electrolytic refining step. In principal all of the electricity consumed in the production of copper could be DC.

2) Since most of the domestic copper mines are located in the western United States (Arizona, New Mexico, and Nevada produced approximately 71 percent of the domestically produced copper ore in 1974), there would actually be an advantage in locating most of the copper production facilities in areas with high insolation.

3) Since copper production is a capital intensive industry, effective use of capital requires full time ojeration, which in turn would require extensive energy storage capacity if solar photovoltaic energy were the major power source. 
LEAD

In 1978, the domestic lead industry consumed approximately 24.8 million kwh of electricity in the smelting of 530 thousand tons of primary lead. Approximately 98 percent of the lead ore mined in the United States comes from the states of Missouri ( 80 percent), Idaho ( 8 percent), Colorado (4 percent) and $U$ tah (1 percent). Most of the domestic lead refinery capacity is located in Missouri, Nebraska, Idaho, Texas and Montana.

With respect to the elements of the criteria for an ideal solar pholuvul= taic powered industry:

1) DC energy can be used to refine lead (Betts Process)

2) Since most of the lead mines are located in the midwest and the west, there would not be much of a problem in locating significant amounts of lead smelting capacity in the Southwestern United States.

3) Lead production is a capital intensive industry and significant amounts of energy storage capacity would be required to fully utilize the lead production capacity if solar photovoltaic enerqy were the primary source. 
ZINC

In 1978, the domestic zinc industry consumed over $108 \mathrm{million} \mathrm{kwh}$ of electricity in the smelting of 470 thousand tons of slab zinc. Approximately 50 percent of the zinc mine production in the United States is located in the midwest and the western states. Most of the rest was located on the East Coast. Since the cost of transporting zinc ores and concentrates is relatively high, most zinc ore is refined fairly close to where it is needed. With respect to the elements of the criteria for an ideal solar photovoltaic powered industry:

1) The most economical method of refining zinc uses $D C$ energy and all of the new zinc production capacity in the world uses this process.

2) Because of high transportation costs only about $46 \%$ of zinc production could be economically located in areas which receive significant amounts of sunshine.

3) Zinc production is capital intensive and significant amounts of energy storage capacity would be required to fully ut ilize the zinc production capacity if solar photovoltaic energy were the primary source. 
$-60-$

CONCLUSION 
of the seven numbers of the Primary Metals industrial group, steel, ferrous castings and $t$ in seem to be the least likely candidates for solar photovoltaic energy use. The location of domestic iron ore in areas with relatively poor insolation and the high cost of transporting this ore to areas with high insolation would seem to disqualify the steel and ferrous castings industries. Whereas, the fact that most of the tin consumed in this country is imported means that there would be little benefit to the domestic energy supply in attempting to substitute solar photovoltaic energy in the tin industry.

On the other hand, the prospects for using solar photovoltaic energy in the copper, lead, zinc and aluminum industries are much more promising. However, before this use becomes feasible new processes will have to be designed which take advantage of the benefits of solar photovoltaic eneray.

Currently, the manufacture of these metals involves the mining and concentration of the various ores at several large and widely distributed mine sites and the shipping of concentrates from several of these mines to a sinqle smelter/refinery. For example, in the domestic copper industry there are approximately 25 mines feeding 15 smelters and in the domestic lead industry there are approximately 31 mines feedina 6 smelters. For economic reasons these metal production processes have tended to be 24 hour operations.

In order to utilize solar photovoltaic energy in these processes and to make effective use of capital it would seem to be possible to alter the current industry structure such that a single mine/concentrator operates on a 24 hour basis to provide enough feed material for a single, sun following photovoltaic powered smelter/refinery. Operating in this way should be cost competitive with current methods of production, qiven the significant savings derived from 
transporting finished metal from the mine site as opposed to transporting ore concentrates. It should also be possible to take advantage of solar's on site energy production capabilities by developing metal production processes which eliminate the concentration and smeltering steps and instead produce metal by direct reduction of the metal ores.

Although the problems associated with developing new processes to produce aluminum arp formidable; the potential rewards are staggering. Currently, the U.S. imports most of its aluminum ore, however, the U.S. contains tremendous reserves of low grade aluminum ore (with an dluminum content of 4.2 to $18 \%$ compared to the $25 \%$ aluminum content of imported bauxite). Much uf this ore is contained in the ail shale deposits of Colorado, Ut ah and Wyoming. As of yet, it has not proven to be economical to mine either the aluminum or the oil shale. If a method of using solar photovoltaic energy can be developed which makes the production of aluminum from this oil shale economical, the resultant increase in the value of the oil shale would make the production of oil from this shale economical. This would have the effect of adding several trillion barrels of oil to the nation's oil reserves (the current reserve is 60 billion barrels). 
BIBLIOGRAPHY 
1. Backus, C.E. (1976). Solar Célls, IEEE Press, New York, N.Y.

2. Brown, M.S., et. al. (1968). The Production, Marketing and Consumption of Copper and Aluminum, F.A. Praeger, New York, N.Y.

3. Chang, Y.A., et. al. (1975). Energy use and Conservation in the Metals Industry, American Institute of Mining, New York, N.Y.

4: Congress of the United States (1978). Application of Solar Technology to Today's Energy Needs, Office of Technology Assessment, Washington, D.C.

5. Considine, D.M. (1977). Energy Technology Handbook, McGraw-Hill, New York, N.W.

6. Farin, P. (1969). Aluminum Profile of An Industry, MicGraw-Hi11, New York, N.Y.

7. McVeigh, J.C. (1977), Sun Power, Pergamion Press, Oxford, England.

8. Nebergall, W.H. et. al. (1976). College Chemistry, D.C. Heath and 'Co., Lexingon, Ma.

9. Smith, C.B. (1976). Efficient Electricity Use: A Practical Handbook for an Energy Constrained World, Pergamon Press, New York.

10. U.S. Department of Commerce. (1979). U.S. Industrial Output, Industry and Trade Administration, Washington, D.C.

11. U.S. Department of the Interior (1975). Mineral Facts and Problems, Bureau of Mines, Washington, D.C. 